\title{
THE ASSOCIATION BETWEEN ORGANIZATION CAPITAL AND FIRM LIFE CYCLE IN INDONESIA
}

\author{
${ }^{1 \text { st }}$ Christa Aurelia Indrawan, ${ }^{2 \text { nd }}$ Vina C.Nugroho \\ \{christaaurelia@yahoo.com ${ }^{1}$, vina.nugroho@uph.edu ${ }^{2}$ \} \\ Universitas Pelita Harapan ${ }^{1,2}$
}

\begin{abstract}
This research investigates about the association between organization capital and firm life cycle. This research classifies the firms' life cycle stage from the operating, financing and investing cash flow. Organization capital is measured using selling, general and administrative expenses (SGA) divided with sum of average growth of SGA in Indonesia with depreciation rate of organization capital. The data used to conduct this research is taken from Indonesian Stock Exchange (BEI), with 10 years' duration from 2006 until 2017. The research result shows that in firms in Indonesia, there is no significant relation between investment in organization capital and a firm's position in the life cycle.
\end{abstract}

Keywords: Organization Capital, Life Cycle Stage of The Firm

\section{Introduction}

To be able to achieve its goal and compete with its competitor in a specific industry, a firm needs a sustainable competitive advantage. Previous research [11] show that firms who had an investment in organization capital have a good basis for a sustainable competitive advantage. An organization capital is a significant component of the production that adds the uniqueness of the firm that creates growth for the entity. Organization capital definition is the knowledge used to combine human skills and physical capital into a system that is used for producing, and delivering products [4]. Moreover, organization capital associated with the firm's attributes, which is the firm's capability to do its operational activity, to make investments and create innovations. As mentioned before, to compete within the competitive market, a firm should have a Sustainable competitive advantage, that can be achieved by investing in organization capital. The organization capital, as a resource that cannot be reorganized and copied easily by its competitors creates a strong value to the company. It clearly shows that the main key to retaining a competitive advantage is to have a nontransferrable organization capital that will be useful for the longer term [11]. Thus, with the competitive advantage, they can maintain their position in the market.

Economists have the idea that the organization capital is affecting a firm's movement in their life cycle's stage [1]. This research shows that role of organization capital is quite significant since the payment from organization capital is more than payments received from net new investment. However, there was no clear explanation of how the movement of a firm in their stage of life cycle. 
Since the previous study done proves that organization capital has a significant contribution to the firm, the author wants to prove whether there is an association between life cycle stages of firms in Indonesia with how much they invest in organizational capital [9]. Since the term of organization capital is not commonly heard in Indonesia, as we often measure a firm's value based on valuing the quantitative and physical aspects only, not seeing specifically on the intangible aspects and viewing the dynamic movement of the firm in the life cycle stage. This research will also provide new information regarding the knowledge of organizational capital and its impact on the life cycle stages of a firm.

\section{$2 \quad$ Literature Review}

\subsection{Organization capital as a resource base to determine a firm life cycle}

Previous research explaining about the impact of investing in organization capital [2]. They noted that organization capital in their definition as an internal language that cannot be carried from the firm by employees that quits from the firm, and it is hard to imitate. Organization capital is important because it acts as the resource base of a firm to achieve competitive advantage, yet it includes all knowledge and processes that allows a firm to utilize physical and human capital on its maximum efficiency to generate higher production and become more productive [9], by then, it will form a critical resource base for a firm [15]. However, no study has explained how a firm life cycle is affected by a firm's organizational capital, as the source of a sustainable resource base. Therefore, since firm life cycle is influenced by the aggregation of firm resources, which is the organizational capital that acts as valuable resource base and the core of a sustainable competitive advantage, the accumulation of firm's knowledge, practices and processes are the main components that can determined a firm's progress and position in their life cycle stages [6].

\subsection{Firm Life Cycle}

Impact of a firm life cycle in the deterimining decision has been demonstrated by Habib and Hasan (2017), They mentioned about the firm's risk-taking in different stages of the life cycle [7]. They proved that in the introduction and decline stage, managerial risktaking is higher than firm in the the shake out stage. Firms in the introduction stage intend to expand their resources by taking risky investment. This strategy also useful to create a good capital capacity in the earlier stage. In the decline stage, firms' probability facing the possibility of exiting the market is big [12]. Hence, they will try to overcome this problem by increasing their investment to regain back their market share. Thus, risk-taking is higher in this stage. However, in the growth and maturity stage, this risk-taking is lower. Growth firm focus on its intention is to prevent competitors from entering the market. Hence, they make an early investment. But since they are creating larger size by diversification and innovation, this requires a lot of managerial decisions. Thus, it needs less risk-taking. Mature firms tend to focus on maintaining its assets in place, so they do less new investment. Therefore, they need less risk-taking. This research shows that the risk taken by a firm is determined by what stages are the firm currently on.

\subsubsection{Classification of firm life cycle}

Each life cycle stages have their characteristics. Firms that move from introduction stage to more mature stage tend to use external financing by issuing debt, as it needs to improve the debt servicing ability [5]. Therefore they will have more cash holding. Following previous study [9], the dependent variable used in the research is the firm life cycle. The identification of life cycle stages is where the combination of a firm's operating, investing and 
financing cash flow gives a firm life cycle mapping at a given time [3]. Using the positive or negative sign of the net operating, investing , and financing cash flow, it gives a combination of several possible cash flow pattern and then will be shortened into five practical life stages (introduction, growth, maturity, decline and shake out).

\subsection{Hypothesis development}

Knowledge and established customer base are the basic factors needed by a firm. Firms in the introduction stage lack in these factors. They do not know the knowledge regarding costs and potential revenues [10]. Huge amount of expenditure in organization capital should be spent in the early stage of a firm's life cycle, as firms can obtain return afterward. Hence, firms in the introduction stage must spent a big amount of costs in expanding for practices, processes, structures ,and employee's training to enhance skills [13]. These costs are more related to operation expenses rather than capital expenses. Large cost of organizational capital and insufficient knowledge base, this results in negative operating cash flow $(\mathrm{OANCF}<0)$ for early stage firms. Negative operating cash flow indicates that the firm is unable to finance its business operations. As a result, higher external financing is required. Thus, a positive cash flow for financing (FINCF > 0) is obtained. Introduction-stage firms seek for long term growth investment, resulting in a negative investing cash flow (INVCF < $0)$. However, knowledge deficiency increased the attractiveness of switching investment from physical capital to organization capital [2]. Alas, a high organization capital with the stated cash flow pattern satisfies the criteria of introduction stage firms.

H1: Firms with high organization capital are more likely to be in the introduction stage.

Characteristics of a firm in the growth stage can be presented by a drastic increase in sales, while on the other side, firms in the maturity stage can be presented by stabilize condition of sales and being a market leader in market industry's competition. Growth firms have passed the critical situations on exit probabilities. Thus they have low (sufficient) knowledge about the competitiveness, and focus on product improvement and innovation. To achieve productivity and growth, both companies in growth and mature have accumulated organization capital that can help them. [1] Companies in these two stages focus on gaining benefits from existing organization capital (organization practices, processes , and corporate culture). Thus, efficiency in production have to increase, and it leads to growth and mature firms to generate positive operating cash flow (OANCF $>0)$. Firms that are on the growth stage tend to increase their operation to capitalize from the benefit gained from existing resources. Hence they are more focused on physical assets investments, and use their capabilities and resource base efficiently [8]. For the maturity stage, they also continue to invest in physical assets, to renew the existing ones [14]. Therefore, both maturity and growth stage firms have negative investing cash flow (IVNCF < 0). For financing, growth firms use debt financing for capital investment that will be used for growth and development, giving the financing cash flow positive (FINCF > 0). However, the maturity stage, since they have limited growth opportunities, they focus on debt servicing and distribution of excess funds among shareholders (FINCF <0). In conclusion, both companies in the growth and maturity stages do not invest more in organization capital, but more on tangible assets and they extract the benefits from existing organization capital. 
H2: Firms with low organization capital are more likely to be in the growth and maturity stages.

\section{Research Method}

\subsection{Empirical model}

$$
\begin{aligned}
\log \left(\frac{\pi_{i t r}}{\pi_{i t 1}}\right)=\alpha_{0} & +\beta_{1} O C_{i t}+\beta_{2} \text { Size }_{i t}+\beta_{3} M T B_{i t}+\beta_{4} \text { Leverage }_{i t}+\beta_{5} \text { ROE }_{i t} \\
& +\beta_{6} \Delta \mathrm{SALE}_{i t}+\beta_{7} \text { Capex }_{i t}+\beta_{8} \mathrm{ATO}_{i t}
\end{aligned}
$$

$\pi$ itr $=\operatorname{Pr}($ Yit $=r)$ are the probabilities of firm in the certain stage of FLC in certain year (introduction, growth, maturity, decline)

$\pi$ it $=$ probability of the shake out stage

\begin{tabular}{|c|c|}
\hline VARIABLE & DATA \\
\hline OC/ PPE & $\begin{array}{l}\text { selling general ,and administrative expense (SGA) } \\
\text { divided with the sum of average growth of SGA } \\
\text { expense and depreciation rate of organization capital. } \\
\text { The Stock of organization capital is measured by } \\
\text { multiplying initial OC with a depreciation rate of OC, } \\
\text { added with SGA value divided with consumer price } \\
\text { index (CPI) } \\
\text { Organization capital estimation from the stock of } \\
\text { organization capital scaled by lagged real Plant, } \\
\text { Property ,and Equipment }\end{array}$ \\
\hline $\begin{array}{l}\text { Firm life } \\
\text { cycle }\end{array}$ & $\begin{array}{l}\text { As a categorical variable that captures the firm's } \\
\text { different stages of the life cycle (Introduction, growth, } \\
\text { maturity, decline, shakeout0 }\end{array}$ \\
\hline Size & Log MVE \\
\hline $\begin{array}{l}\text { Market to } \\
\text { book }\end{array}$ & MVE divided with BVE \\
\hline Leverage & total debt divided with lagged total assets \\
\hline ROE & operating income divided with total equity \\
\hline 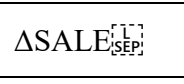 & $\begin{array}{l}\text { Differences between sales each year scaled by total } \\
\text { sales }\end{array}$ \\
\hline CAPEX & Capital expenditure scaled by lagged total assets \\
\hline ATO & net sales divided with total assets \\
\hline
\end{tabular}

\section{Table 1. Operationalization of variables}

\section{Result and Discussion}

\subsection{Descriptive Statistics}

Table 2. Range of all variables

\begin{tabular}{lll}
\multicolumn{1}{c}{ Variable } & Minimum & Maximum \\
\hline $\begin{array}{l}\text { Independent variable } \\
\text { OC/PPE }\end{array}$ & 0.00218 & 17.24226 \\
Control variable & & \\
Capital Expenditure & 0 & 0.3024853
\end{tabular}




\begin{tabular}{lll} 
Delta sales & -0.93306 & 7.07212 \\
MTB & -4.62396 & 35.37978 \\
Size & 6.91641 & 14.06900 \\
Asset turnover & 0.00172 & 4.25844 \\
Leverage & 0 & 2.885536 \\
ROE & -1.07826 & 1.72810 \\
\hline
\end{tabular}

Source: Data processed by author (2018)

The amount of organization capital in firms in Indonesia ranged from 0.00218 to 17.24226. The gap is quite big, due to the big differences between the selling and general administrative expense (SGA) and the amount of investment in property, plant, and equipment (PPE). Some firms in Indonesia has almost no investment in the property and equipment, but they spent a large amount of expenses. OC/PPE is an independent variable. The organization capital is measured by calculating selling and general administrative (S\&GA) expense with Consumer Price Index and depreciation of organization capital. Organization capital is measured using S\&GA expense because according to Hasan and Cheung (2017) [9] the S\&GA expense can capture the amount of organization capital spent by a company since organization capital is the accumulation of organization processes, practices , and systems. SGA is expected to capture all the cost related to employee training and information technology (IT). From the result above, this shows that firms in Indonesia have bigger organization capital in the introduction and decline stages, and companies in the growth and mature condition invest less on the organization capital.

\subsection{Regression Result}

Table 3. Regression Result

\begin{tabular}{|c|c|c|c|c|c|c|c|c|}
\hline & \multicolumn{2}{|c|}{ Model 1} & \multicolumn{2}{|c|}{ Model 2} & \multicolumn{2}{|c|}{ Model 3} & \multicolumn{2}{|c|}{ Model 4} \\
\hline & Coef & $P>z$ & Coef & $P>x$ & Coef & $\mathbf{P}>\mathbf{z}$ & Ceef & $P>z$ \\
\hline $\mathrm{OC} / \mathrm{PPE}$ & -0.03933 & 0.362 & -0.00135 & 0.986 & -0.02468 & 0.531 & -0.00767 & 0.927 \\
\hline CAPEX & 3.01955 & 0.359 & 3.89321 & 0.295 & 4.90501 & 0.056 & 3.79779 & 0.380 \\
\hline$\Delta$ Sales & 0.07056 & 0.775 & 0.12549 & 0.536 & 0.18928 & 0.472 & 0.02921 & 0.921 \\
\hline MTB & 0.11189 & 0.066 & -0.01495 & 0.871 & -0.00505 & 0.899 & 0.19467 & 0.388 \\
\hline Size & -0.01360 & 0.927 & 0.40183 & 0.331 & 0.11297 & 0.224 & -0.28260 & 0.671 \\
\hline ATO & 0.01723 & 0.938 & 0.60898 & 0.032 & 0.04926 & 0.824 & 0.38735 & 0.270 \\
\hline Leverage & 0.00539 & 0.991 & 0.10326 & 0.900 & -0.02989 & 0.925 & 0.25768 & 0.836 \\
\hline ROE & 0.02536 & 0.135 & -0.11356 & 0.838 & -0.14862 & 0.652 & 1.03591 & 0.263 \\
\hline F test & & 18.07 & & 10.67 & & 0.80 & & 10.86 \\
\hline Prob $>\mathrm{Chi}^{2}$ & & 0.0207 & & 0.2288 & & 0.6043 & & 0.2099 \\
\hline
\end{tabular}

The first hypothesis stated that firms that have higher organization capital is tend to be in the introduction stage since they invest more on the knowledge base and systems for the firm in the early stages. Introduction stage tends to spend bigger expenditure on organization capital because they need to create a good foundation for the company. They focus more on creating firm organization practices and enhance their employee skills. On the other hand, the second hypothesis stated that firms with low organization capital would be more likely to be on growth or maturity stage, due to more investment on physical capital rather than adding 
more on organization capital. They already have sufficient knowledge and experience practices, and they have already accumulated their organization capital. Both stages also focus on investing more on tangible assets. Hence, they do not need to invest more in the organization capital.

Model 1 is the regression for the introduction stage. This model is treated with the bootstrap method. Under this method, the probability of this model reflects a significant impact. The significance of this model is seen from probability lower than 0.05 , which is 0.0207. The OC/PPE indicates the organization capital of a firm in this stage, shows a reversed result. Under this introduction model, the OC/PPE is insignificant. The insignificance is reflected from the p-value of 0.362 . This result leads to a rejection of the first hypothesis, with a requirement of $\mathrm{p}$-value lower than $5 \%$. Moreover, the coefficient of the OC/PPE itself is negative. Based on the hypothesis that Hasan and Cheung (2017) [9] stated, the coefficient should have a positive result in following the given hypothesis. However, the negative coefficient indicates a vice versa effect of the organization capital towards the introduction stage.

From model 1, the hypothesis statement rejected is hypothesis 1 . Hypothesis 1 stated that firms with high organization capital are more likely to be in the introduction stage. With negative coefficient and insignificant p-value, the result shows that in the introduction stage, firms that have higher organization capital are less likely to be in the introduction stage. But since the probability is not significant, this means that firms with high or low organization capital do not have any significant impact on the introduction stage.

Growth stage regression result is reflected in Model 2. Model 2 is also treated using the bootstrapping method. The result from this method shows that probability is equal to 0.22 and this means that the model is not significant because the probability is bigger than $5 \%$. OC/PPE or organization capital showing a negative coefficient, and the probability p-value of 0.986 . Based on Hasan and Cheung (2017) hypothesis, the coefficient should be negative. Thus, the negative coefficient of organization capital in growth stage follows the hypothesis. However, null hypothesis is rejected, since p-value is bigger than $5 \%$, showing that the probability is not significant.

The third model is the regression used for maturity stage. Model 3 is treated using the jackknife method. Probability model obtained from this method is 0.60 , again showing the insignificance of the model because the probability is bigger than 0.05 . The coefficient for OC/PPE shows a negative number and the probability of 0.531 . Negative coefficient here also follows the hypothesis stated, but the result is insignificant because $\mathrm{p}$-value is bigger than $5 \%$. Therefore, the null hypothesis is rejected.

Hypothesis 2 stated that firms with low organization capital are more likely to be in the growth and maturity stage. Since both growth and maturity stage rejected the null hypothesis, this means that hypothesis 2 is rejected. Although negative coefficient shows that firms with low organization capital are likely to be in the growth and maturity stage, p-value of OC/PPE is insignificant, and probability model of this regression is insignificant. This means that the model itself is not significant. Firms that have low or high organization capital is neither in the growth or maturity stage.

Lastly, model 4 is for the decline stage. Insignificance can be seen from the probability model. The probability model is 0.209 , which is larger than 0.05 . Coefficient of OC/PPE is negative, and the probability of p-value is 0.962 . This shows that for this model also, the probability is not significant since $\mathrm{p}$-value is larger than 0.05 . The probability model is also not significant, meaning that the regression model is not significant. 
Since both of hypothesis is rejected, the overall result shows that the investment in organization capital does not have any significant impact on the company's life cycle in Indonesia. Whether the investment in organization capital is high or low, it does not reflect the position or the movement of the company in its life cycle stages. This result can conclude that in Indonesia, firm life cycle stages cannot be determined by how much they invest in organization capital. Moreover, with the insignificant probability of the model, it shows that organization capital phenomenon is not captured in firms in Indonesia.

\section{Conclusion}

The result of the regression shows that both of hypotheses stated are rejected. This showed, that the main idea of the hypothesis cannot be proven in Indonesia. The result appears that value of organization capital does not determine the position of a firm's in life cycle stage for firms in Indonesia. Hence, this means that in Indonesia, the value of organization capital does not have any impact on a firm life cycle. The result from the regression is not as what the hypothesis has stated, this is probably due to the lack number of observation and due to a limitation to access the data. Another cause can be due to the different measurement of organization capital between The United States and Indonesia. The measurement used in United States seems to be inappropriate to be used in Indonesia. This may have happened because Indonesia and The United States have different standards and formats of financial statement. United States use GAAP (Generally Accepted Accounting Principle), while Indonesia follows PSAK/IFRS (Pernyataan Standard Akutansi Keuangan / International Financial Report Standard). Therefore, the result is not what it is expected to be.

Moreover, this result may be affected by the inaccuracy of the method to classify the firm life cycle stages. Since in Indonesia the requirement for firms to be listed publicly are quite strict, including the minimum age of the firm, minimum profit and minimum equity invested. By looking only from the requirement to be listed in the stock exchange, it can be said that firms in Indonesia that are listed are on more mature stage, so the result that shows firms are on the introduction stage can be concluded incorrectly.

\section{References}

[1]Atkeson, A., \& Kehoe, P. J. (2005). Modeling and measuring organization capital. Journal of Political Economy, 113(5), 1026-1053.

[2]Carlin, B.I., Chowdhry, B., Garmaise, M.J., 2012. Investment in organization capital. Journal of Financial Intermediation, 21(2), 268-286.

[3]Dickinson, V. (2011). Cash flow patterns as a proxy for firm life cycle. The Accounting Review, 86(6), 1969-1994.

[4]Evenson, R. E., \& Westphal, L. E. (1995). Technological change and technology strategy. Handbook of development economics, 3, 2209-2299.

[5]Faff, R., Kwok, W. C., Podolski, E. J., \& Wong, G. (2016). Do corporate policies follow a life-cycle? Journal of Banking \& Finance, 69, 95-107.

[6]Gort, M., \& Klepper, S. (1982). Time paths in the diffusion of product innovations. The economic journal, 92(367), 630-653.

[7]Habib, A., \& Hasan, M. M. (2017). Firm life cycle, corporate risk-taking and investor sentiment. Accounting \& Finance, 57(2), 465-497.

[8]Hambrick, D. C., MacMillan, I. C., \& Day, D. L. (1982). Strategic attributes and performance in the BCG matrix-A PIMS-based analysis of industrial product businesses. Academy of Management Journal, 25(3), 510-531.

[9]Hasan, M. M. \& Cheung, A. (2017). Organization capital and firm life cycle. Journal of Corporate Finance, 48, 556-578. 
[10]Jovanovic, B. (1982). Selection and the Evolution of Industry. Econometrica: Journal of the Econometric Society, 649-670.

[11]Lev, B., \& Radhakrishnan, S. (2005). The valuation of organization capital. In Measuring capital in the new economy(pp. 73-110). University of Chicago Press.

[12]Lev, B., Radhakrishnan, S., \& Zhang, W. (2009). Organization capital. Abacus, 45(3), 275-298.

[13]Pérez, S. E., Llopis, A. S., \& Llopis, J. A. S. (2004). The determinants of survival of Spanish manufacturing firms. Review of Industrial Organization, 25(3), 251-273.

[14]Wernerfelt, B. (1985). The dynamics of prices and market shares over the product life cycle. Management Science, 31(8), 928-939.

[15]Wright, P. M., Dunford, B. B., \& Snell, S. A. (2001). Human resources and the resource based view of the firm. Journal of management, 27(6), 701-721. 